DOI: 10.17707/AgricultForest.65.4.22

\begin{abstract}
Sabri EL MOUATASSIME*, Ahmed BOUKDIR, Ismail KARAOUI, Goran SKATARIC, Marina NACKA, Abdulvahed KHALEDI DARVISHAN, Paul SESTRAS, Velibor SPALEVIC ${ }^{1}$
\end{abstract}

\title{
MODELLING OF SOIL EROSION PROCESSES \\ AND RUNOFF FOR SUSTAINABLE WATERSHED MANAGEMENT: CASE STUDY OUED EL ABID WATERSHED, MOROCCO
}

\begin{abstract}
The study was carried out in the watershed of Oued El Abid that is located upstream of the Bin El Ouidane Dam in Morocco. Looking for a sustainable watershed management practices, we estimated soil losses from the river basin and the sediment yield deposited in the dam of Bin El Ouidane, using the Intensity of Erosion and Outflow - IntErO model, based on the Erosion Potential Method - EPM. The watershed of the lake receiving the waters and sediments from the two mean water courses Oued El Abid and Assif Ahansal, therefore before to proceed the calculation, the watershed was divided in two sub basins; the soil erosion and sediment yield were calculated for each sub basin. The result of calculation for the studied Oued El Abid river basin showed that the production of erosion material in the river basin is $3.960 .115 \mathrm{~m}^{3} \mathrm{yr}^{-1}$. Coefficient of the deposit retention, calculated using the IntErO model, was 0.3 and as a consequence, real soil losses were calculated on $1.188 .657 \mathrm{~m}^{3} \mathrm{yr}^{-1}$; specific real soil losses per $\mathrm{km}^{2} 402 \mathrm{~m}^{3} \mathrm{~km}^{2} \mathrm{yr}^{-1}$. Our findings, based on Gavrilovic classification, pointed out that the studied area is with a medium potential of soil erosion risk, due to the steep land slope and low vegetation cover in the watershed. The model outcome is validated using the Bathymetry measurements in the Dam of Bin El Ouidane.

Keywords: Soil erosion, IntErO Model, Land Use, Runoff, Soil erosion, Soil conservation

\section{INTRODUCTION}

Soil erosion is one of the most important causes of land degradation and one of the key global environmental hazards; especially for developing countries

\footnotetext{
${ }^{1}$ Sabri El Mouatassime (*correspondence: sabri.elmouatassime@gmail.com), Ahmed Boukdir, Ismail Karaoui, Sultan MoulaySlimane University, Department of Geology, Beni Mellal, MOROCCO; Goran Skataric, National Parks of Montenegro, Podgorica, MONTENEGRO; Marina Nacka, Faculty of Agricultural Sciences and Food, Skopje, Ss. Cyril and Methodius University in Skopje, NORTH MACEDONIA; Abdulvahed Khaledi Darvishan, Department of Watershed Management Engineering, Faculty of Natural Resources, Tarbiat Modares University, Noor, IRAN; Paul Sestras, Department of Land Measurements and Cadastre, Faculty of Civil Engineering, Technical University of Cluj-Napoca, Cluj-Napoca, ROMANIA; Velibor Spalevic, University of Montenegro, Faculty of Philosophy, Geography, Danila Bojovica, Niksic, MONTENEGRO.

Note: The authors declare that they have no conflicts of interest. Authorship Form signed online.
} 
(Eswaran et al, 2001), affecting all natural and human-managed ecosystems (Kalibová et al., 2016; Gholami et al., 2013). Soil erosion by water affects 1,094 million hectares of arable land worldwide (Noor et al, 2013).

According to the various available reports $33 \%$ of the continental land is degraded, mainly by the use of agrochemicals, deforestation and water erosion. Among them, water erosion is considered the principal and most widespread agent of soil degradation, causing the reduction of productive capacity and the environmental devastation (Kinnell, 2016). In the Mediterranean neighbourhood of the studied basin, in Europe, data on trends in soil erosion are lacking and erosion estimates are based on modelling studies. In the 1990s, water erosion affected 105 million hectares of soil or 16\% of Europe's total land area. In 2006, it was estimated that the surface area affected by water erosion 37 in the EU-27 was 130 million hectares (Spalevic, 2011). In 2014-15, approximately $11.4 \%$ of the EU territory was affected by moderate to high level water erosion rate (more than 5 tonnes per hectare per year). The reduction of this rate against 1990s by $4.6 \%$ is mainly due to the application of water erosion control practices which have been applied during the last decade in the EU.

For the appropriate sustainable watershed management, land use and landscape planning, which will more effectively meet national or local needs and assists in assessing the consequences of the alternatives the important issue is to quantify the sediments and to estimate sediment yield at the river basin scale (Chalise et al., 2019; Spalevic, 2019; Curovic et al, 2019; Parsipour et al, 2019, Fikfak et al, 2017; Popovic et al, 2018). Sediment sampling in the rivers need a lot of time and costly laboratorial works. Therefore, developing models with ability of estimating total amount of sediment is an inevitable need (Das and Agrawal, 1990; Khaledi Darvishan et al, 2010). Modelling of the erosion process is of a vital importance and various research teams developed models to predict soil loss - sediment yield, peak discharge - runoff. That can be used for the analysis of long as well as short periods of time (Spalevic, 2017a; 2017b; Barovic et al., 2015, Khaledi Darvishan et al., 2014; Sadeghi et al., 2013).

In the recent time we recorded the shortfall of rain and the problems of the storage capacity of the river dams in Morocco. In Bin El Ouidane Dam, in the Middle Atlas, the reservoir reached an unpreceded level of storage, almost $16 \%$ of its total capacity, just as the empty concrete pipes that snake in the plains to irrigate more than 100,000 hectares of beet, cereals and fruit trees; the point where the agriculture irrigation was no longer possible. The consequences can be disastrous while the country depends on agriculture, this sector, which draws $88 \%$ of the country's water consumption, supports $40 \%$ of the population and accounts for $15 \%$ of GDP.

This alert called for more interest to dam siltation problem caused by soil erosion and sediment yield, including the reservoir sedimentation in the Oued el Abid Watershed (Sabri et al. 2017).

We used the computer-graphic "River Basin" model of Spalevic (Spalevic, 1999) and the IntErO model (Spalevic, 2011) for prediction of soil erosion 
intensity and sediment yield in the Bin El Ouidane Dam. This models calculate inputs using analytics of the Erosion Potential Method (EPM), originally developed by Gavrilovic (1972). This approach has been tasted earlier in many catchments area in Bosnia \& Herzegovina, Bulgaria, Croatia, Czech Republic, Italy, Iran, Montenegro, Macedonia, Serbia and Slovenia and Morocco (Behzadfar, et al., 2014; Kostadinov et al., 2006; Gholami et al, 2016; Khaledi Darvishan et al, 2016, 2017; Vujacic et al, 2017). In Morocco have been successfully used in the Region of Western Rif of Morocco (Ouallali et al. 2016).

This study aims to identify the erosion processes in relation to the recent state of the sediment yield in the dam of Bin El Ouidane downstream the watershed of Oued el Abid in Morroco. This included the previous research results on the same watershed and precedent bathymetry measurements in the same dam, using different way of modelling sediment yield by the IntErO model that could be used for the efficient management and protection in the basins with similar climate and physical-geographical conditions.

\section{MATERIALS AND METHODS}

Study Area. Morocco, where the study area of Oued El Abid watershed is located, is in Northern Africa, bordering the North Atlantic Ocean and the Mediterranean Sea, between Algeria and Western Sahara. Position of this area is strategic with the location along Strait of Gibraltar; and it is the only African country to have both Atlantic and Mediterranean coastlines.

Terrain is placed between the mountainous northern coast (Rif Mountains) and interior (Atlas Mountains) bordered by large plateaus with intermontane valleys, and fertile coastal plains. Mean elevation of this area is $909 \mathrm{~m}$, the lowest point, Sebkha Tah is $-59 \mathrm{~m}$ and highest point is Jebel Toubkal, 4,165 m. Agricultural land covers $67.5 \%$, arable land, $17.5 \%$, with permanent crops of $2.9 \%$ and permanent pasture of $47.1 \%$. Forests cover $11.5 \%$ (other: $21 \%$ ).

Northern mountains are geologically unstable and subject to earthquakes; periodic droughts; windstorms; flash floods; landslides. This region characterise soil erosion resulting from farming of marginal areas, overgrazing, destruction of vegetation; but also some water and soil pollution due to dumping of industrial wastes into the ocean and inland water sources, and onto the land.

Oued El Abid watershed The study was conducted upstream the Bin El Ouidane dam and is with a total surface of $3119 \mathrm{~km}^{2}$, in the high Atlas chain in the region of Beni Mellal Khenifra, Morroco. The drainage area of Oued El Abid is presented on the Figure 2. The Bin El Ouidane Dam accumulates the water comes from two rivers and the water is used for irrigation and hydraulic power production.

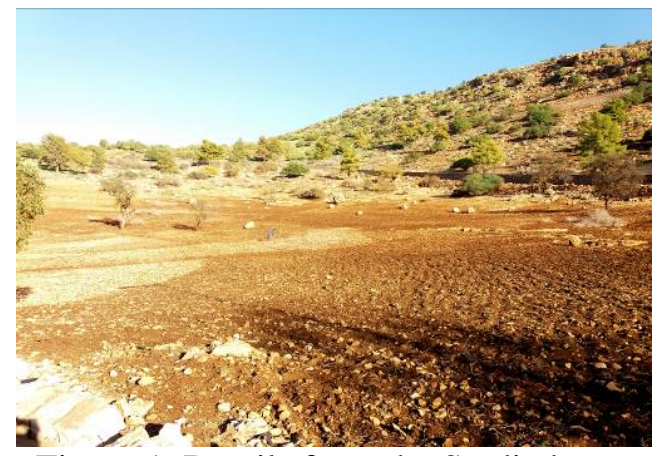

Figure 1. Details from the Studied area (Photo: Velibor Spalevic, 11/2017) 

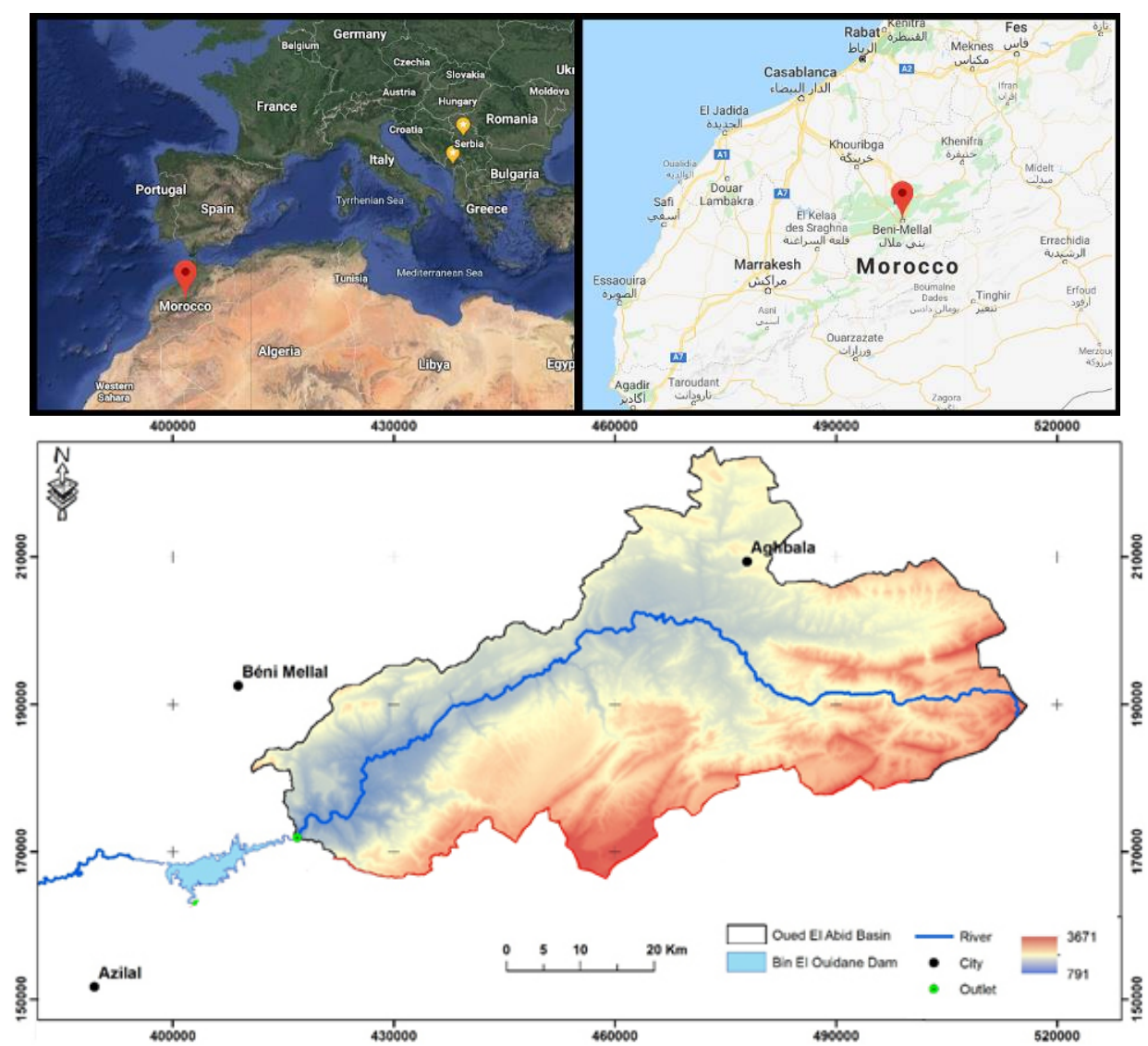

Figure 2. Study area of the Oued El Abid Watershed, Morocco

\section{Soil Erosion IntErO model}

Soil erosion models have been developed worldwide. Some of these are chemical runoff and erosion from agricultural management systems - CREAMS (Knisel, 1980), areal nonpoint source watershed environment response simulation - ANSWERS (Beasley et al 1980), agricultural nonpoint source pollution model - AGNPS (Young et al, 1987), water erosion prediction project - WEPP (Nearing et al, 1989), Universal Soil Loss Equation - USLE, Modified Universal Soil Loss Equation - MUSLE and Revised Universal Soil Loss Equation RUSLE (Wischmeier and Smith, 1978: Williams, 1975; Renard, 1991) and MUSLT (Nicks et al, 1994; Sadeghi et al, 2013).

Sediment delivery ratio (SDR), transport limiting sediment delivery (TLSD), unit stream power erosion and deposition model (USPED), and sediment distributed delivery (SEDD) have been used to model the sediment removal, transportation, and delivery. Employing soil erosion models to estimate the soil erosion severity at a place is gaining popularity nowadays as field-based erosion studies are tedious, costly, and take a considerable amount of time. 
Instead, soil erosion models can assess the soil loss within a short time, provided data are available handy (Chalise et al, 2019).

The Erosion Potential Method - EPM (Gavrilovic, 1972) describe the annual sediment yield and transport, the forms and intensity of erosion, from the physical-geographic and hydrological characteristics of the river basin. It is most often used in Europe, North Africa and the Middle East. In recent times the EPM is repeatedly applied in several watersheds in the Mediterranean area, especially in the South East Europe - Balkan region (Blinkov and Kostadinov, 2010; Kostadinov et al., 2006, 2014; Milevski et al., 2008; Spalevic et al. 2013, Spalevic et al. 2014; Spalevic et al. 2015; Spalevic et al. 2016; Stefanovic, 2004; Tazioli, 2009; Tavares et al., 2019), and also in arid and semi-arid areas of the south-western USA (Gavrilovic Z., 1988), Saudi Arabia (Aburas Al-Ghamdi, 2010). The method was based on the factors affecting erosion in a watershed; its parameters were dependent on the temperature, the mean annual rainfall, the soil use, the geological properties and some other factors in the watershed scale (Gholami et al, 2016; Khaledi Darvishan et al., 2016, 2017). The synergic influences of climate and human abandonment could have triggered erosion processes.

The Intensity of Erosion and Outflow - IntErO program package (Spalevic, 2011) with the EPM embedded in the algorithm of this model, was developed to predict the runoff peak discharge and the intensity of soil erosion in a watershed scale. The use of this model has been reported in various countries all around the world including Bosnia \& Herzegovina, Bulgaria, Croatia, Czech Republic, Italy, Iran, Montenegro, Macedonia, Serbia, Slovenia, Morocco, Brazil and Nepal. The efficiency of IntErO model to predict peak outflow, soil erosion and sediment yield was also assessed in some cases and the results showed that this model can be use in variety of watershed sizes with various land uses (Spalevic, 2011).

The present study was conducted to use the IntErO for modelling of soil erosion processes and runoff for sustainable watershed management to predict peak outflow, soil erosion and sediment yield for the Oued El Abid Watershed in Morocco.

The IntErO model estimates the total erosion yield on the catchment level and quantifies the hydro-sedimentological parameters using the equations 1-5:

$$
\begin{array}{ll}
\mathrm{W}_{\mathrm{yr}}=T_{i} \cdot \mathrm{H}_{\mathrm{yr}} \cdot \pi \cdot \sqrt[n]{\mathrm{Z}^{3}} \cdot \mathrm{F} & \text { Equation } 1 \\
T_{i}=\sqrt[2]{\frac{\mathrm{t}_{\mathrm{o}}}{10}}+0.1 & \text { Equation 2 } \\
\mathrm{Z}=\mathrm{Y} \cdot \mathrm{X}_{\mathrm{a}} \cdot\left(\varphi+\sqrt[2]{\mathrm{I}_{\mathrm{gr}}}\right) & \text { Equation 3 } \\
\mathrm{G}_{\mathrm{yr}}=\mathrm{W}_{\mathrm{yr}} \cdot \mathrm{R}_{\mathrm{u}} & \text { Equation 4 } \\
\mathrm{R}_{\mathrm{u}}=\frac{(\mathrm{O} \cdot \mathrm{D})^{0.5}}{0.25 \cdot(\mathrm{L} v \cdot 10)} & \text { Equation 5 }
\end{array}
$$


where: $\mathrm{W}_{\mathrm{yr}}=$ Annual erosion $\left(\mathrm{m}^{3} \mathrm{~km}^{-2} \mathrm{yr}^{-1}\right) ; \mathrm{T}_{\mathrm{i}}=$ Coefficient of temperature (dimensionless); $\mathrm{H}_{\mathrm{yr}}=$ Mean annual rainfall $\left(\mathrm{mm} \mathrm{yr}^{-1}\right) ; \mathrm{Z}=$ Coefficient of erosion (dimensionless); $\mathrm{F}=$ Basin area $\left(\mathrm{km}^{2}\right) ; \mathrm{t}_{0}=$ Mean air temperature $\left({ }^{\circ} \mathrm{C} \mathrm{yr}^{-1}\right) ; \mathrm{Y}=$ Soil resistance to erosion (dimensionless); $\mathrm{X}_{\mathrm{a}}=$ Coefficient of soil use and management (dimensionless); $\varphi=$ Coefficient of visible erosion features (dimensionless); $\mathrm{I}_{\mathrm{sr}}=$ Mean slope (\%); $\mathrm{G}_{\mathrm{yr}}=$ Sediment production $\left(\mathrm{m}^{3} \mathrm{~km}^{-2} \mathrm{yr}^{-1}\right)$; $\mathrm{R}_{\mathrm{u}}=$ Coefficient of retention (dimensionless); $\mathrm{O}=$ Basin length $(\mathrm{km}) ; \mathrm{D}=$ Difference in basin elevation (m) and; Lv = Length of main stream (km).

The analysis of the Geological and Physical and chemical soil properties were done at laboratory based on soil survey and geological maps (scale 1:500.000). To obtain accurate analytical results, each of the 143 soil samples was reported based on the mean of five subsamples taken within a $1000 \mathrm{~m}^{2}$ area.

The meteorological data obtained from the measurements of two meteorological stations in the last 50 years (1970-2019), the physical characteristics were extracted from a Digital Elevation Model using Gis tools. The land cover data has obtained after a radiometric- atmospheric treatments and classification of satellite images.

After the field visit, but also using all the available data from the Soil and Geological surveys, receiving the relevant data from the local Hydro meteorological stations, and analysing the satellite images we completed the table with the inputs needed for calculations with the IntErO model. The input data needed for modelling of erosion processes are presented in the Table 1.

Table 1. Input data needed for modelling of soil erosion processes and runoff

\begin{tabular}{|l|c|r|c|}
\hline Inputs & Symbol & Value & Unit \\
\hline River basin area & $\mathrm{F}$ & 3119.14 & $\mathrm{~km}^{2}$ \\
\hline The length of the watershed & $\mathrm{O}$ & 484.16 & $\mathrm{~km}$ \\
\hline Natural length of the main watercourse & $\mathrm{Lv}$ & 175.85 & $\mathrm{~km}$ \\
\hline The shortest distance between the fountainhead and mouth & $\mathrm{Lm}$ & 93.79 & $\mathrm{~km}$ \\
\hline The length of the main watercourse with tributaries & $\mathrm{L}$ & 58984.36 & $\mathrm{~km}$ \\
\hline River basin length measured by a series of parallel lines & $\mathrm{Lb}$ & 130 & $\mathrm{~km}$ \\
\hline The area of the bigger river basin part & $\mathrm{Fv}$ & 2272.15 & $\mathrm{~km}^{2}$ \\
\hline The area of the smaller river basin part & $\mathrm{Fm}$ & 846.99 & $\mathrm{~km}^{2}$ \\
\hline Altitude of the first contour line & $\mathrm{h} 0$ & 900 & $\mathrm{~m}$ \\
\hline The lowest river basin elevation & $\mathrm{Hmin}$ & 791 & $\mathrm{~m}$ \\
\hline The highest river basin elevation & $\mathrm{Hmax}$ & 3699 & $\mathrm{~m}$ \\
\hline A part of the basin with very permeable product from rocks & $\mathrm{fp}$ & 0.2 & \\
\hline A part of the river basin area consisted of medium permeable rocks & $\mathrm{fpp}$ & 0.32 & \\
\hline A part of the basin consisted of poor water permeability rocks & $\mathrm{fo}$ & 0.48 & \\
\hline A part of the river basin under forests & $\mathrm{fs}$ & 0.49 & \\
\hline A part of the basin under grass, pastures and orchards & $\mathrm{ft}$ & 0.32 & \\
\hline A part under bare land, plough-land and ground without grass & $\mathrm{fg}$ & 0.19 & \\
\hline The volume of the torrent rain & $\mathrm{hb}$ & 112.8 & $\mathrm{~mm}$ \\
\hline Average annual air temperature & $\mathrm{t} 0$ & 16.8 & ${ }^{\circ} \mathrm{C}$ \\
\hline Average annual precipitation & $\mathrm{Hyr}$ & 347.1 & $\mathrm{~mm}$ \\
\hline Types of soil products and related types & $\mathrm{Y}$ & 1.4 & \\
\hline coefficient of the river basin planning & $\mathrm{Xa}$ & 0.91 & \\
\hline Numeral equivalents of visible erosion process & $\varphi$ & 0.5 & \\
\hline
\end{tabular}




\section{RESULTS AND DISCUSSIONS}

After preparing the inputs required for IntErO model, the model was ran and all the model outputs were obtained and shown in Table 2 .

Table 2. Modeling results for the Oued El Abid Watershed, Morocco

\begin{tabular}{|c|c|c|c|}
\hline Results & Symbol & Value & Unit \\
\hline Coefficient of the river basin form & A & 0.58 & - \\
\hline Coefficient of the watershed development & $\mathrm{m}$ & 0.8 & - \\
\hline Average river basin width & $\mathrm{B}$ & 24.62 & $\mathrm{~km}$ \\
\hline (A)symmetry of the river basin & $\mathrm{a}$ & 0.17 & - \\
\hline Density of the river network of the basin & $\mathrm{G}$ & 18.82 & - \\
\hline Coefficient of the river basin tortuousness & $\mathrm{K}$ & 1.55 & - \\
\hline Average river basin altitude & $\mathrm{Hsr}$ & 1975.12 & $\mathrm{~m}$ \\
\hline Average elevation difference of the river basin & $\mathrm{D}$ & 1325.12 & $\mathrm{~m}$ \\
\hline Average river basin decline & Isr & 2.17 & $\%$ \\
\hline The height of the local erosion base of the river basin & Hleb & 2576 & $\mathrm{~m}$ \\
\hline Coefficient of the erosion energy of the basin's relief & Er & 111.22 & - \\
\hline Coefficient of the region's permeability & S1 & 0.66 & - \\
\hline Coefficient of the vegetation cover & S2 & 0.74 & - \\
\hline water retention in inflow & $\mathrm{W}$ & 8763.61 & $\mathrm{~m}$ \\
\hline Energetic potential of water flow during torrent rains & $2 \mathrm{gDF}^{\wedge} 1 / 2$ & 2845.94 & $\mathrm{~m} \mathrm{~km} \mathrm{~s}$ \\
\hline Temperature coefficient of the region & $\mathrm{T}$ & 1.33 & \\
\hline Coefficient of the river basin erosion & $\mathrm{Z}$ & 0.796 & \\
\hline Production of erosion material in the river basin & Wyr & 3960115 & $\mathrm{~m}^{3} \mathrm{yr}-1$ \\
\hline Coefficient of the deposit retention & $\mathrm{Ru}$ & 0.3 & \\
\hline Real soil losses & Gyr & 1188657 & $\mathrm{~m}^{3} \mathrm{yr}-1$ \\
\hline Real soil losses per $\mathrm{km}^{2}$ & Gyr $\left(\mathrm{km}^{2}\right)$ & 402.39 & $\mathrm{~m}^{3} \mathrm{~km}^{2} \mathrm{yr}^{-1}$ \\
\hline
\end{tabular}

With the modelling of the erosion processes at the Oued El Abid Watershed, in Morocco we concluded that there is a possibility for large flood waves to appear in the studied river basin. The value of $G$ coefficient of 18.82 indicates that there is very high density of the hydrographic network in the studied river basin. Calculations showed that in the river basin prevail mild slopes. The strength of the erosion process is high, and according to the erosion type, it is surface erosion.

In 2015 the team led by Sabri el Mouatassime in the watershed of Oued El Abid, using the USLE model came out with a result of sediment yield which shows that an annual amount of soil loss of 5.2 million $\mathrm{m}^{3}$ reaches the dam of Bin El Ouidane downstream the watershed. Our research showed that annual real soil losses for the Oued El Abid Watershed in Morocco are 1.2 million $\mathrm{m}^{3}$. The other, unpublished result from the same team of researchers, calculated annual real soil losses for both river basins: Oued El Abid and the Tillouguite basin, that all together counts on 4.1 million $\mathrm{m}^{3}$. Analysing the bathymetric measurement for the period 1953-2008, sediment yield rate resulted to 5 million $\mathrm{m}^{3}$ year ${ }^{-1}$. The tributaries are inflowing from the northeast and southeast and that most but not all sediments are depositing from those two rivers, the result of modelling by using the IntErO is quite satisfactory. 


\section{CONCLUSION}

Different geographical factors and hydrological processes govern sediment dynamics in the studied river basin, which are highly variable in spatial and temporal scales. The IntErO is an appropriate technique for modelling of soil erosion processes to estimate the soil losses by water erosion in the conditions similar to the study area of Oued El Abid Watershed, Morocco. For the conditions of the studied area, the USLE model is providing slightly higher results (4\% higher than the bathymetric measurements). The IntErO modelling provided about $10 \%$ less than measurements for this specific case. Both models proof to be useful for modelling of soil erosion processes and runoff for the needs of sustainable watershed management.

\section{REFERENCES}

Aburas Al-Ghamdi, S. (2010). Application of Gavrilovic' Model for water erosion hazards in wadinaman basin through remote sensing and GIS techniques. p43, www.dr-aburas.com.

Barovic, G., Leandro Naves Silva, M., Veloso Gomes Batista, P., Vujacic, D., Soares Souza, W., Cesar Avanzi, J., Behzadfar M., Spalevic, V. (2015): Estimation of sediment yield using the IntErO model in the S1-5 Watershed of the Shirindareh River Basin, Iran. Agriculture and Forestry (61) 3: 233-243

Beasley, D.B.; Huggins, L.F.; Monke, E.J. ANSWERS: A model for watershed planning. Trans. ASAE 1980, 23, 938-944.

Behzadfar, M., Tazioli, A., vukelic-Shutoska, M., Simunic, I., Spalevic, V. (2014). Calculation of Sediment Yield in the S1-1 Watershed, Shirindareh Watershed, Iran. Agriculture \& Forestry, 60(4): 207-216.

Blinkov, I. \& Kostadinov, S., (2010). Applicability of various erosion risk assessment methods for engineering purposes, BALWOIS 2010 Conference - Ohrid, Republic of Macedonia. 25 - 29 May 2010.

Chalise, D., Kumar, L., Spalevic, V., Skataric, G. (2019). Estimation of Sediment Yield and Maximum Outflow Using the IntErO Model in the Sarada River Basin of Nepal. Water, 11, 952.

Curovic, Ž.; Curovic, M.; Spalevic, V.; Janic, M.; Sestras, P.; Popovic, S.G (2019). Identification and Evaluation of Landscape as a Precondition for Planning Revitalization and Development of Mediterranean Rural Settlements-Case Study: Mrkovi Village, Bay of Kotor, Montenegro. Sustainability 2019, 11, 2039

Das, G., Agrawal, A., (1990). Development of Conceptual Sedimentgraph Model. Am J Agr. E., 33(1), 100-104.

Eswaran, H.; Lal, R.; Reich, P.F.; others. (2001): Land degradation: an overview. Responses to L. Degrad. 20-35.

Fikfak, A., Spalevic, V., Kosanovic, S., Popovic, S., Djurovic, M., Konjar, M. (2017): Land Use Development of Vineyards Areas in Goriska Brda, Slovenia. Notulae Botanicae Horti Agrobotanici Cluj-Napoca: 45(2):611-622.

Gavrilovic, S. (1972). Inzenjering o bujicnim tokovima i eroziji. Izgradnja. Beograd.

Gavrilović, Z. (1988). The use of empirical method (erosion potential method) for calculating sediment production and transportation in unstudied or torrential streams. In: White, W. R. (ed.), International Conference on River Regime; 411-422. Chichester.

Gholami, L., Batista, P.V.G., Behzadfar, A., Darvishan, A.K. and Behzadfar, M., 2016. Application of IntErO model for soil loss estimation case study: S7-1 Watershed of Shirindareh river basin, Iran. In VII International Scientific Agriculture Symposium," Agrosym 2016", 6-9 October 2016, Jahorina, Bosnia and Herzegovina. Proceedings (pp. 2169-2177). University of East Sarajevo, Faculty of Agriculture.

Gholami, L., Sadeghi, S.H.R., Homaee, M. (2013), "Straw mulching effect on splash erosion, runoff and sediment yield from eroded plots. Soil Science Society of America Journal, 77: 268278. 
Kalibová, J., Jacka, L., Petru, J. (2016): The effectiveness of jute and coir blankets for erosion control in different field and laboratory conditions. Solid Earth 7 (2), 469-479. http://dx.doi.org/10.5194/se-7-469-2016.

Khaledi Darvishan A., Behzadfar M., Spalevic V., Kalonde P., Ouallali A., Mouatassime E.S. (2017). Calculation of sediment yield in the S2-1 watershed of the Shirindareh river basin, Iran, Agriculture and Forestry, 63(3): 23-32.

Khaledi Darvishan, A., Derikvandi, M., Aliramaee, R., Khorsand, M., Spalevic, V., Gholami, L., Vujacic, D. (2016). Efficiency of IntErO Model to Predict Soil Erosion Intensity and Sediment Yield in Khamsan Representative Watershed (West of Iran). Agrofor, 3(2): 22-31.

Khaledi Darvishan, A., Sadeghi, S. and Gholami, L., (2010). Efficacy of Time-Area Method in simulating temporal variation of sediment yield in Chehelgazi watershed, Iran. Annals of Warsaw University of Life Sciences-SGGW. Land Reclamation, 42(1): 51-60.

Khaledi Darvishan, A., Sadeghi, S.H.R., Homaee, M. Arabkhedri, M. (2014). Measuring Sheet Erosion using Synthetic Color-Contrast Aggregates. Hydrological Processes, 28(15): 44634471

Kinnell PIA. A review of the design and operation of runoff and soil loss plots. Catena. 2016;145:257-65. https://doi.org/10.1016/j.catena.2016.06.013

Knisel, W.G. CREAMS: A Field Scale Model for Chemicals, Runoff, and Erosion from Agricultural Management Systems; Conservation Research Report (USA); Dept. of Agriculture: Washington, DC, USA, 1980.

Kostadinov, S., Zlatic, M., Dragovic, N. \& Gavrilovic, Z. (2006). Soil erosion in Serbia and Montenegro. In Boardman, J., Poesen, J. (eds), Soil Erosion in Europe. John Wiley \& Sons, Ltd; London, 271-277.

Milevski, I., Blinkov, I. \& Trendafilov, A. (2008). Soil erosion processes and modeling in the upper Bregalnica catchment. XXIVth Conference of the Danubian Countries. On the hydrological forecasting and hydrological bases of water management, 2-4 June 2008, Bled, Slovenia. p190.

Nearing, M.A.; Foster, G.R.; Lane, L.J.; Finkner, S.C. A process-based soil erosion model for USDA-Water Erosion Prediction Project technology. Trans. ASAE 1989, 32, 1587-1593

Nicks, A. D., Williams, J. R., Williams, R. D. and Gander, G. A. (1994). 1994. Estimating erosion with models having different technologies. In: Proceedings 25th annual conference, international erosion control association, 15-18 February 1994, Reno, NV. Neveda: International Erosion Control Association, 51-61.

Noor, H.; Fazli, S.; Alibakhshi, S.M. (2013): Evaluation of the relationships between runoff-rainfall-sediment related nutrient loss (A case study: Kojour Watershed, Iran). Soil Water Res 2013, 8, 172-177.

Ouallali A., Moukhchane M., Aassoumi H. et al. (2016). The mapping of the soils degradation state by adaptation the PAP/RAC guidelines in the watershed of Wadi Arbaa Ayacha, Western Rif, Morocco. Journal of Geoscience and Environment Protection, 4, 77-88.

Parsipour, H., Popovic, S., Behzadfar, M., Skataric, G., Spalevic, V. (2019). Cities expansion and land use changes of agricultural and garden lands in peri-urban villages (case study: Bojnurd). Agriculture and Forestry, 65(3): 173-187

Popovic, S., Spalevic, V., Skataric, G. Kosanovic, S. (2018): Land degradation caused by illegal construction in the Bjelopavlici Plain: Case study of the narrow belt along the motorway Podgorica - Danilovgrad, Montenegro. Book of Abstracts, Green Room Sessions 2018 International GEA (Geo Eco-Eco Agro) Conference, Podgorica, Montenegro, p 153.

Renard, K.G.; Foster, G.R.; Weesies, G.A.; Porter, J.P. RUSLE: Revised universal soil loss equation. J. Soil Water Conserv. 1991, 46, 30-33.

Sabri, el., Boukdir, A., El Meslouhi, R., Mabrouki, M., El Mahboul, A., Zitouni, A. (2017): Predicting Soil Erosion and Sediment Yield in Oued El Abid Watershed, Morocco. Athens Journal of Sciences, 4(3): 225-243.

Sadeghi, S.H.R., Gholami, L., Khaledi Darvishan, A. (2013). Suitability of MUSLT for storm sediment yield prediction in Chehelgazi watershed, Iran. Hydrological Sciences Journal, 58(4): 892-897.

Spalevic, V. (2019). Assessment of Soil Erosion Processes by Using the 'IntErO'Model: Case Study of the Duboki Potok, Montenegro. Journal of Environmental Protection and Ecology, 20(2): 657-665. 
Spalevic, V., Lakicevic, M., Radanovic, D., Billi, P., Barovic, G., Vujacic, D., Sestras, P., Khaledi Darvishan, A. (2017a): Ecological-Economic (Eco-Eco) modelling in the river basins of Mountainous regions: Impact of land cover changes on sediment yield in the Velicka Rijeka in Montenegro. Notulae Botanicae Horti Agrobotanici Cluj-Napoca: 45(2):602-610.

Spalevic, V., Radanovic, D., Skataric, G., Billi. P., Barovic, G., Curovic, M., Sestras, P., and Khaledi Darvishan A. (2017b): Ecological-economic (eco-eco) modelling in the mountainous river basins: Impact of land cover changes on soil erosion. Agriculture and Forestry, 63 (4): 925. DOI:10.17707/AgricultForest.63.4.01

Spalevic, V., Barovic, G., Fikfak, A., Kosanovic, S., Djurovic, M., and Popovic, S. (2016). Sediment yield and Land use changes in the Northern Montenegrin Watersheds: Case study of Seocki Potok of the Polimlje Region. Journal of Environmental Protection and Ecology: 17 (3): 990-1002.

Spalevic, V., Curovic, M., Barovic, G., Vujacic, D., Tunguz, V. and Djurovic, N. (2015). Soil erosion in the river basin of Provala, Montenegro. Agriculture and Forestry, 61(4): 133-143.

Spalevic, V., Radanovic, D., Behzadfar, M, Djekovic, V., Andjelkovic, A., Milosevic, N. (2014). Calculation of the sediment yield of the Trebacka Rijeka, Polimlje, Montenegro.Agriculture and Forestry, 60(1): 259-272.

Spalevic, V., Djurovic, N., Mijovic, S., Vukelic-Sutoska, M., Curovic, M. (2013). Soil erosion intensity and runoff on the Djuricka River basin (North of Montenegro). Malaysian Journal of Soil Science, 17: 49-68.

Spalevic, V. (2011). Impact of land use on runoff and soil erosion in Polimlje. Doctoral thesis, Faculty of Agriculture of the University of Belgrade, Serbia, p 1-260.

Spalevic, V., Dlabac, A., Jovović, Z., Rakočević J, Radunović, M., Spalevic, B., Fuštić, B. (1999). The "Surface and distance Measuring" Program. Acta Agriculture Serbica, Vol IV, 8, p.63-71, Serbia. ISSN 0354-9542.

Stefanovic, M., Gavrilovic, Z. \& M. Milojevic, M. (2004). Erosion potential method and erosion risk zoning in mountainous regions. In Internatioales Symposion Iterprevent-RivalTrient.

Tavares, S., Spalevic, V., Avanzi, J., Nogueira, D., Silva, M.L.N., Mincato, R.L. (2019). Modelling of water erosion by the erosion potential method in a pilot sub basin in southern Minas Gerais. Semina: Ciências Agrárias, Londrina, 40(2): 555-572.

Tazioli, A. (2009). Evaluation of erosion in equipped basins: preliminary results of a comparison between the Gavrilovic model and direct measurements of sediment transport. Environmental Geology, 56(5), 825-831.

Vujacic, D., Barovic, G., Djekovic, V., Andjelkovic, A., Khaledi Darvishan, A., Gholami, L., Jovanovic, M. and Spalevic, V. (2017): Calculation of Sediment Yield using the "River Basin" and "Surface and Distance" Models: A Case Study of the Sheremetski Potok Watershed, Montenegro. Journal of Environmental Protection and Ecology, 18(3): 1193-1202.

Williams, J. Sediment routing for agricultural watersheds. J. Am. Water Resour. Assoc. 1975, 11, 965-974.

Wischmeier, W.H.; Smith, D.D. Predicting rainfall erosion losses-a guide to conservation planning. In Predicting Rainfall Erosion Losses-A Guide to Conservation Planning; USDA, Science and Education Administration: Hyattsville, MD, USA, 1978.

Wischmeier, W.H.; Smith, D.D. Predicting Rainfall-Erosion Losses from Cropland East of the Rocky Mountains: Guide for Selection of Practices for Soil and Water Conservation; Agricultural Research Service, US Department of Agriculture: Washington, DC, USA, 1965; Volume 282.

Young, R.; Onstad, C.; Bosch, D.; Anderson, W. AGNPS, Agricultural Non-Point-Source Pollution Model: A Watershed Analysis Tool; Conservation Research Report 35; US Dept. of Agriculture: Washington, DC, USA, 1987. 